\title{
PROPER PLACEMENT OF INDEPENDENT-LEANERS \\ IN THE PARTISAN IDENTIFICATION SCALE: DATA FROM TWO ARKANSAS SAMPLES
}

\author{
Michael A. Maggiotto \\ (Bowling Green State University) \\ Gary D. Wekkin \\ (University of Central Arkansas)
}

What is an independent-leaner? More than a generation has passed since the Michigan NES/CPS group established its now standard, seven-point scale of classification of partisan identifiers [Campbell, et. al. 1960]; yet, suddenly, the correct way to conceptualize the different types of independent identifiers and interpret their behavior has re-emerged as an unresolved problem for students of political behavior.

The problem was identified as a result of Petrocik's [1974] analysis of intransitivities in the seven-point scale of partisan identification. If the scale were indeed a valid operationalization, then a monotonic relationship should have been found to exist between the various categories of identification and level of political activity. Such was not the case, however. Independent-leaners were found to be more active then weak identifiers on several measures of civic virtue. Accounting for this inconsistency spurred subsequent questioning of both the operational definition and the measurement of partisan identification.

Maggiotto and Piereson [1977] found that the factoring in of partisaii 1dentifiers' evaluations of the opposition party improved upon the ability of the standard, unidimensional partisan index to explain and predict electoral behavior. They concluded by calling for a multiple-indicator approach to the study of partisan identification that distinguished affect toward the party with which one identified from affect toward the opposition party. Katz [1979], who found that interparty changers tended to retain their intensity of attachment (i.e., strong Democrats and strong Republicans appeared to be closer to each other than either were to independents), concluded that partisan identifiers entertain a certain amount of identification with the idea of 
particularly for the purpose of compelling policy fidelity (Hitlin and Jackson, 1979: 619). According to the authors, the three dimensions are listed in ascending order of difficulty with regard to implementation in the American system. Figure 1 illustrates this multidimensional concept of the party continuums (Hitlin and Jackson, 1979: 620).

\section{Figure 1}

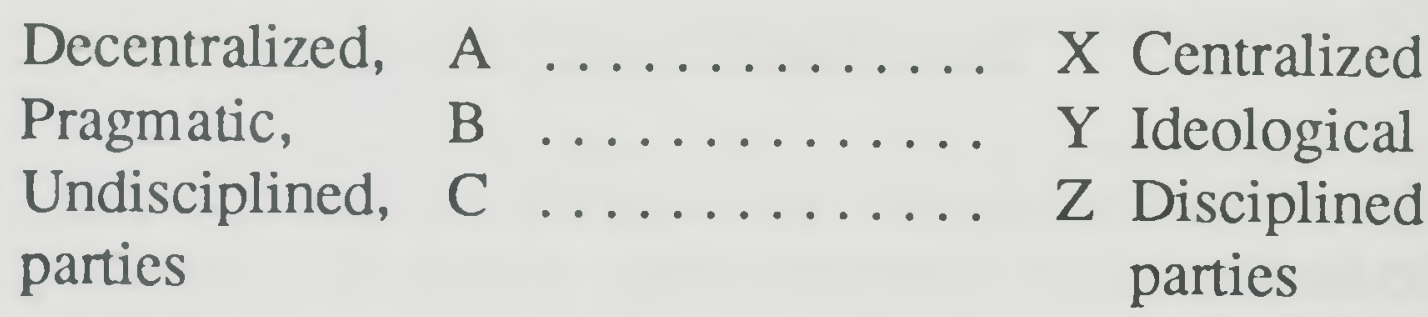

While this article will not address all dimensions of responsible party behavior, it will concentrate on the degree to which the political party elites (Democratic and Republican) offer meaningful and significant choices to the American voter, i.e., the pragmatic-ideological dimension. To date, the studies focusing on party elites and their philosophical and party positions vis-a-vis the American public have been small in number, but fairly consistent in their findings. In nearly every case the research has been based upon the pioneering work of Herbert McClosky and his associates (1960).

In this seminal piece, McClosky and colleagues presented their findings as a refutation of the general image of American political parties differing only slightly from one another in principle and doctrine. Using data comparing the 1956 national convention delegates to the mass public, McClosky demonstrated empirically that American political elites and followers existed along an ideological continuum. In particular, it was noted that Democratic delegates were consistently more liberal than Democratic identifiers with respect to certain public policy issues. Similarly, Republican delegates were shown to be more conservative than the Republican rank-and-file. McClosky attributed these differences in political opinion to the fact that the delegates were "political elites". Moreover, it was discovered that the views of the Republican rank-and-file were "much closer to those of the Democratic leaders than to those of the Republican leaders" (1960:422).

The McClosky study was not fully replicated until Jeane Kirkpatrick's (1976) study of 1972 Republican and Democratic national conventions. In keeping with the McClosky study, Kirkpatrick found 
sizable differences between the Republican and Democratic Party elites (1972 national convention delegates) on four of the five policy issues selected for study. However, in stark contrast to McClosky's earlier finding, Kirkpatrick observed substantial differences between the Democratic Party's elite and their own rank-and-file. In Kirkpatrick's own words:

By 1972 the position of Republican and Democratic elites has been reversed and the Democractic presidential elite was 'odd-man out.' The Republican presidential elite more faithfully mirrored the views and values of their own party identifiers and of voters generally than did the Democratic elite which did not reflect the views of ordinary Democrats or of voters generally (1976: $315)$.

In a key study by Montjoy, Shaffer, and Weber (1980), responses were analyzed from a nationwide sample taken in 1972 of county chairmen and party followers on ten issues of state policy. Like McClosky and Kirkpatrick, Montjoy and associates document considereable cleavage between Republican and Democratic leaders on most of the issues. Unlike Kirkpatrick, Montjoy and his collegues found the Republican elites to be the "odd-man out" with Democratic and Republican followers and Democratic elites holding similar political views. In their conclusion, the authors state that "as a group the Republican elites represent neither their own followers nor the followers of the other party on most of our ten policy questions"' (Montjoy et al., 1980, 334-335).

While these results differ sharply from those presented by Kirkpatrick, it should be pointed out that Kirkpatrick and Montjoy used two different populations in sampling for party elites. Kirkpatrick used the more traditional population of national convention delegates, while Montjoy used a national sample of county chairmen. Furthermore, the "type" of issues examined was different in both studies. Kirkpatrick dealth with national policy issues, while Montjoy concentrated on state policy concerns. These differences might have contributed to the conflicting results.

Finally, the most significant recent addition to this genre of literature was completed by Jackson et al. (1982). In this study, Jackson extended the definition of "political elites" to encompass such groups as: national convention delegates, county and state chairs, and national committee members. When compared to the mass base of the two parties for 1980 , Jackson reported "dramatic" interparty differences with the Democratic Party elites comprising the liberal alternative and the Republican 
Party elites the conservative choice in the American political system. Party identifiers were located in the ideological middle with Democratic identifiers leaning toward the left and Republican identifiers leaning toward the right. In a follow-up study, Jackson (1985) duplicated his previous findings while focusing on party elites and the mass voters of 1984.

At first blush the cumulative evidence of these nationwide studies is impressive. ${ }^{1}$ The data clearly depict an image of Democratic Party leaders, rank-and-file voters, and Republican Party leaders arrayed along a political continuum, from left to right, sharply divided over various policy issues. This is a far cry from Lord Bryce's early 20th century observation that American parties were as similar as Tweedledum and Tweedledee - or George Wallace's more recent pronouncement that "there's not a dime's worth of difference" between the Democratic and Republican Parties. Yet, despite these consistent empirical findings, no distinction is made between party elites or followers from different regions. This is important for as Sharkansky cogently notes:

There is generally no awareness that findings produced by a fifty-state analysis may differ considerably from what exists in the environments of different regions (1970:8).

Even ideologies within each political party may vary from one region to the next (Sorauf and Beck, 1988). Thus, this research is the first of its kind in attempting to bridge this gap in the literature.

Nowhere is the image of regionalism more vivid than that of the South ${ }^{2}$. For more than a hundred years the South has been "the" distinctive American region (Reed, 1982). ${ }^{3}$ Beginning with V.O. Key's (1949) classic analysis of southern politics, the portrayal of southerm culture has been one characterized by low levels of political participation, one-party politics, racial conflict, elitism, paternalism, parochialism, agrarianism, and religious fundamentalism, to name a few. ${ }^{4}$ This is a region whose alienation from mainstream America for over seventy years following Reconstruction lead to the creation of a cultural identity and political solidarity unparalleled in American history (Harvard, 1986).

According to Daniel Elazar, real political power in the South is restricted to a

relatively small and self-perpetuating group drawn from an established elite who often inherit their right to govern through family ties or social position (1984:119). 
Political leaders are encouraged to play "conservative and custodial rather than initiatory roles" "unless pressed by the elite-oriented political order (Elazar, 1984:119). Southern political parties are often considered weak and ineffectual. Hence, political competition is conducted through factional alignments, the result of personalized politics (Black and Black, 1982; Whistler and Ellickson, 1988).

Thus the South is an extremely important region to bring under closer inspection. On the one hand, nationwide elite-mass studies have clearly indicated that party leaders, relative to mass voters, are significantly divided over important substantive policy issues; yet, the preponderance of studies aimed at southern culture suggest much greater homogeneity among party leaders and mass voters alike. Given these contradictory findings and the dearth of elite-mass studies focusing solely on the Confederate South, we have decided to state our hypotheses in the null format. With this in mind, the following hypotheses are presented to the reader.

\section{Hypotheses}

Hypothesis 1: Southern Democratic and Republican Party elites will exhibit no significant differences in their leadership stands on selected issues of foreign and domestic importance and a self-identified political ideology index (interparty hypothesis).

Hypothesis 2: Southern Democratic and Republican Party leaders will not differ significantly from the southern mass electorate in their viewpoints on selected public policy issues and a self-identified ideological index (elite-mass hypothesis).

Hypothesis 3: There will be no significant within-mass voter differences in terms of their position on the issue items and ideological index. Specifically, southem Democratic identifiers, Independents, and Republican identifiers, will not manifest any substantive differences on the various issues and index (intraelectorate hypothesis).

\section{Data and Methodology}

The data to be analyzed in this study are a subset of John S. Jackson's 1984 Party Elite data set. ${ }^{5}$ The eight different groups of Democratic and Republican Party elites in this study are as follows:

(1) The delegates to the 1984 Democratic National Convention

(2) The members of the Democratic National Committee (DNC) 
(3) The State Chairs for the Democratic Party

(4) The County Chairs for the Democratic Party

(5) The delegates to the 1984 Republican National Convention

(6) The members of the Republican National Committee (RNC)

(7) The State Chairs for the Republican Party

(8) The County Chairs for the Republican Party

The data were collected by way of a mail questionnaire that was sent to the Democratic and Republican Party elites (in 1984) after each party's national convention in July and August, respectively. A second wave was mailed in September and October to all those who had not yet responded. There was a total of 2,310 usable questionnaires returned after the second wave representing an overall return rate of 51 percent. ${ }^{6}$ This return rate compares favorably to those of other major studies of this sort. For example, McClosky's (1960) return rate was approximately 44 percent, while Kirkpatrick's (1976) return rate was 55 percent overall.

With regard to the national convention delegates for both parties, a systematic random sample was drawn from official lists provided by the Democratic and Republican Parties. For members of the DNC and RNC, as well as the Democratic and Republican state chairs, the entire population was included. The Republican county chairs were selected at random from an official party list, while the Democratic county chairs were randomly selected from a list compiled by Jackson and his associates. Furthermore, data pertaining to Independents and the party rank-andfile were culled from the Center for Political Studies 1984 National Election Survey (the Pre-Post version).

The use of multiple surveys to tap the views and opinions of party leaders and followers necessitates using the same questions from one survey to the next. In this study the following questions were selected from the Jackson and Center for Political Studies 1984 surveys. These questions deal with domestic and foreign policy issues, as well as ideology.

The research methodology in this study consisted of using one-way analysis of variance in conjunction with the Student-Newman-Keul's multiple comparisons test. These statistical techniques are considered appropriate when comparing three or more group means simultaneously (Champion, 1981). Note also that only political party elites, party identifiers, and Independents from the Confederate South were utilized in this study. They were drawn from the larger Jackson and National Election Survey data sets, mentioned above. Furthermore, the eight 


\section{Table 1}

\section{Survey Questions on Selected Issues - 1984}

1. Ideology (self-indentification)

Response Range: Very Liberal - Very Conservative

2. Respondents' Position on Govemment Services Response Range: Cut Services - No Cuts

3. Respondents' Position on Government Job Guarantees Response Range: Government Job Guarantee - Laissez-Faire

4. Respondents' Position on Affirmative Action Respoonse Range: Help Minorities - No Special Effort

5. Respondents' Position on Womens' Right Response Range: Place is in the Home - Equal Role With Men

6. Respondents' Position on Abortion

Response Range: Never Permitted - Woman's Choice

7. Repondents' Position on National Health Insurance Response Range: Government Health Insurance - Private Health Insurance

8. Respondents' Position on Defense Spending Response Range: Cut - Increase

9. Respondents' Position on Detente Response Range: Pro - Anti

The following five questions dealt with balancing the federal budget. The response range was either yes or no.

10. Cut Education Spending to Balance the Budget?

11. Cut Social Security to Balance the Budget?

12. Cut Welfare to Balance the Budget?

13. Cut Health/Medicare to Balance the Budget?

14. Cut Defense Spending to Balance the Budget? 
elite groups represented in the Jackson data sets were collasped into two groups (Southern Democratic Party elites and Southern Republican Party elites) for ease and clarity of presentation and to maintain acceptable $n$ sizes.

\section{Findings and Discussion}

In Tables 2 and 3 we have provided the results of the party clite groups compared to the mass public on the various issue items and selfidentified ideological index. Table 2 displays the cross-tabulations, while Table 3 summarizes the statistical relationships between all party elite and mass voter groupings.

Beginning with the self-identified index there was little support for our hypotheses. Partisan division was far more pronounced than expected with the southern Democratic elites assuming a moderate-toliberal position and the GOP elites an unadulterated conservative stance. Specifically, four out of five southern GOP elites identified themselves as conservatives, while no Republican leaders opted for the liberal alternative. In contrast, only $15 \%$ of the southem Democratic elites aligned themselves with the conservative perspective, but $58 \%$ did place themselves in the moderate category.

The spatial distribution of mean values, shown in Figure 2, illustrates the moderate-to-conservative leanings of the southern rank-and-file as well as the GOP elite. For example, over two-thirds of all Republican identifiers and nearly $45 \%$ of all southern Independents reported conservative responses. Southern Democratic rank-and-file tended to split their views equally among the liberal (29\%), moderate (40\%), and conservative (32\%) positions. The spatial perspective also points out that the differences between southern Democratic and Republican Party leaders are far more pronounced than those exhibited by the mass voters suggesting that real ideological alternatives exist for the southern mass.

These findings then serve to reinforce the conservative image of southern politics long portrayed in the literature (Key, 1949; Bartley, 1969; Bartley and Graham, 1975; Hill, 1977). However, the lack of southern homogeneity among party leaders and followers alike tends to contradict this very same literature. While it is difficult to project from a single finding, these results do portend a possible shift in southem politics. As habitual Democratic presidential voting in the South comes to a close, some speculate that the South is entering an era of 
Table $2^{*}$

\section{Policy Preferences of Southern Party Elites, Identifiers, and Independents - 1984}

\section{GROUP}

ISSUE

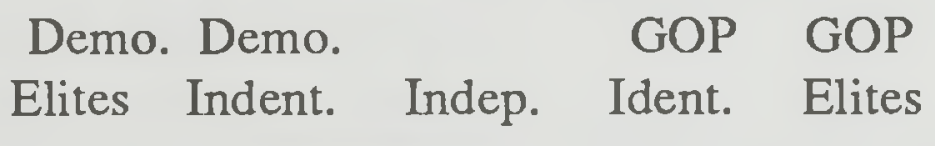
$\% \quad \% \quad \% \quad \% \quad \%$

Ideology:

$\begin{array}{llllll}\text { Liberal } & 28 & 29 & 20 & 15 & 0 \\ \text { Moderate } & 58 & 40 & 35 & 17 & 20 \\ \text { Conservative } & 15 & 32 & 44 & 67 & 80 \\ \quad N= & (315) & (157) & (133) & (92) & (315) \\ * * \mathrm{X}= & 1.87 & 2.03 & 2.24 & 2.52 & 2.80\end{array}$

Government Service:

$\begin{array}{llllll}\text { Liberal (No Cuts) } & 36 & 30 & 16 & 14 & 3 \\ \text { Moderate } & 58 & 58 & 68 & 58 & 53 \\ \text { Conserv. (Pro Cuts) } & 6 & 12 & 16 & 28 & 44 \\ \quad N= & (316) & (215) & (183) & (105) & (314) \\ \quad \mathrm{X}= & 1.70 & 1.81 & 2.01 & 2.13 & 2.40\end{array}$

Goverment Job Guarantee:

$\begin{array}{llllll}\text { Liberal (Yes) } & 20 & 37 & 28 & 19 & 2 \\ \text { Moderate } & 62 & 46 & 49 & 44 & 21 \\ \text { Conservative (No) } & 18 & 17 & 23 & 37 & 77 \\ \quad N= & (311) & (224) & (201) & (111) & (315) \\ \mathrm{X}= & 1.98 & 1.80 & 1.95 & 2.18 & 2.75\end{array}$

NHI:

$\begin{array}{llllll}\text { Liberal (Yes) } & 34 & 32 & 30 & 27 & 4 \\ \text { Moderate } & 44 & 49 & 46 & 39 & 29 \\ \text { Conserv. (No) } & 22 & 19 & 25 & 34 & 67 \\ \quad N= & (312) & (84) & (88) & (44) & (312) \\ \quad \mathrm{X}= & 1.88 & 1.87 & 1.95 & 2.07 & 2.63\end{array}$

Affirmative action action:

$\begin{array}{llllll}\text { Liberal (Yes) } & 22 & 28 & 17 & 10 & 3 \\ \text { Moderate } & 60 & 56 & 57 & 63 & 48 \\ \text { Conservative (No) } & 18 & 16 & 26 & 27 & 49 \\ \quad N= & (312) & (224) & (194) & (108) & (310) \\ \quad \mathrm{X}= & 1.96 & 1.88 & 2.09 & 2.17 & 2.45\end{array}$


Abortion:

$\begin{array}{llllll}\begin{array}{r}\text { Liberal (Woman's } \\ \text { Choice) }\end{array} & 49 & 27 & 26 & 31 & 17 \\ \begin{array}{l}\text { Moderate } \\ \text { Conserv. (Never }\end{array} \quad 19 & 18 & 20 & 20 & 16 \\ \quad \text { Permitted) } & 32 & 55 & 54 & 49 & 66 \\ \quad(297) & (266) & (231) & (121) & (307) \\ \quad \mathrm{X}= & 1.84 & 2.27 & 2.28 & 2.17 & 2.52\end{array}$

Women's Rights

Liberal (Pro

Equality)

Moderate

Conserv. (Trad.

Roles)

$\begin{array}{llllll}N= & (316) & (244) & (201) & (112) & (305) \\ \mathrm{X}= & 1.34 & 1.63 & 1.68 & 1.71 & 1.62\end{array}$

Defense Spending:

Liberal (Pro Cuts)

Moderate

25

Conserv. (No Cuts)

$$
\begin{aligned}
& N= \\
& \mathrm{X}=
\end{aligned}
$$

70

47

43

44

44

26

43

45

41

51

4

10

11

15

6

Detente:

Liberal (Pro)

Moderate

Conserv. (Anti)

$$
\begin{aligned}
& N= \\
& \mathrm{X}=
\end{aligned}
$$

25
70

25

18

$8 \quad 1$

5

59

59

$60 \quad 72$

$\begin{array}{llll}17 & 23 & 32 & 26\end{array}$

(315)

(222)

(188)

(108)

(312)

1.80

1.92

2.05

$2.23 \quad 2.25$

Programs to be Cut:

$\begin{array}{clllll}\text { Education (Yes) } & 8 & 3 & 7 & 6 & 49 \\ N= & (317) & (232) & (194) & (104) & (311) \\ \mathrm{X}= & 1.08 & 1.03 & 1.07 & 1.06 & 1.49\end{array}$

$\begin{array}{ccllll}\text { Social Security (Yes) } & 8 & 2 & 7 & 3 & 30 \\ \quad N= & (317) & (234) & (199) & (106) & (311) \\ \mathrm{X}= & 1.08 & 1.02 & 1.07 & 1.03 & 1.30 \\ & & & & & \\ \text { Welfare (Yes) } & 38 & 28 & 37 & 43 & 89 \\ \quad N= & (317) & (229) & (188) & (105) & (311) \\ \mathrm{X}= & 1.38 & 1.28 & 1.37 & 1.43 & 1.89\end{array}$




$\begin{array}{clllll}\text { Health/Medicare (Yes) } & 13 & 3 & 4 & 4 & 51 \\ N= & (317) & (236) & (196) & (105) & (311) \\ \mathrm{X}= & 1.13 & 1.03 & 1.04 & 1.04 & 1.51 \\ & & & & & \\ \text { Defense (Yes) } & 77 & 19 & 17 & 11 & 33 \\ N= & (317) & (225) & (192) & (1.03) & (311) \\ \mathrm{X}= & 1.77 & 1.19 & 1.17 & 1.11 & 1.33\end{array}$

*On all tables the mean scores range from 1.00 (most liberal) to 3.00 (most conservative). The first nine questions were originally based on a 5-or 7-point Likert-type format where $1=$ most liberal answer and 5 or $7=$ most conservative answer. We collasped all Likert-type questions into three categories (liberal, moderate, or conservative) for clarity of presentation and to ensure respectable cell sizes.

**For a discussion of the effects of using mean scores with ordered data in large sample sizes see: E. L. Lehman, Nonparametrics: Statistical Methods Based on Ranks (San Francisco: Holden-Day, 1975), 76-81. 


\section{TABLE 3}

\section{Comparison of Policy Preferences of Southern}

Party Elites, Identifiers, and Independents - 1984

$\begin{array}{ll}\text { ISSUE } & \text { No Significant Mean DifferencesDetected Between } \\ \text { Ideology } & \text { (significant differences between all groups) }\end{array}$

Government Services

Government Job Guarantee

NHI

Affirmative Action

Abortion

Women's' Rights

Defense Spending

Detente

Education Cuts

Social Security Cuts

Welfare

Health/Medicare Cuts

Defense
Key: Democratic Elites $=1$
Democratic Identifiers $=2$
Independents $=3$
GOP Identifiers $=4$
GOP Elites $=5$

* Mean comparisons were conducted using one-way analysis-of-variance and StudentNewman-Keul's multiple comparison test with $\mathrm{p}<.05$.

For ease and clarity of presentation, Figure 2 portrays the spatial distribution of the mean values of all groups for each topic. 


\section{FIGURE 2}

Spatial Distribution of Issue Items and Ideological Identification for Part Elite and Mass Groupings—1984

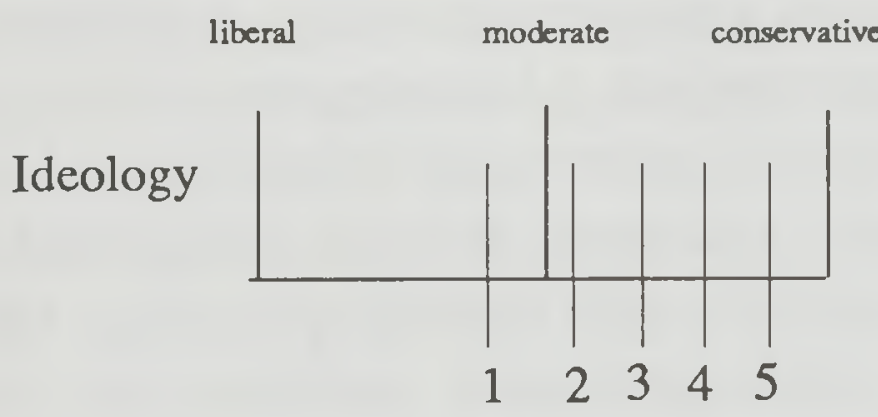

liberal moderate conservative

Gov't

Services

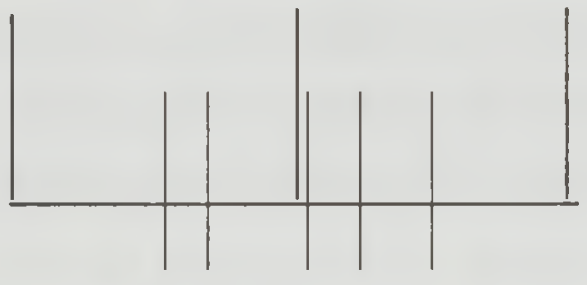

12345

Gov't Job Guarantees

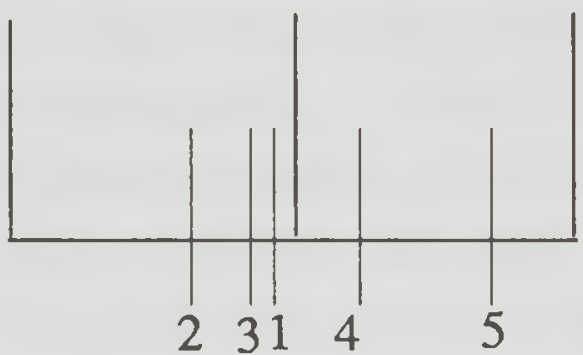

NHI

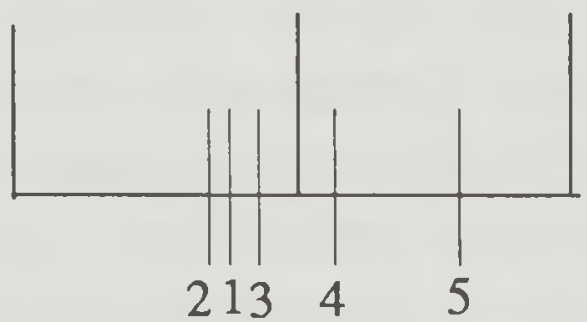

Affirmative Action

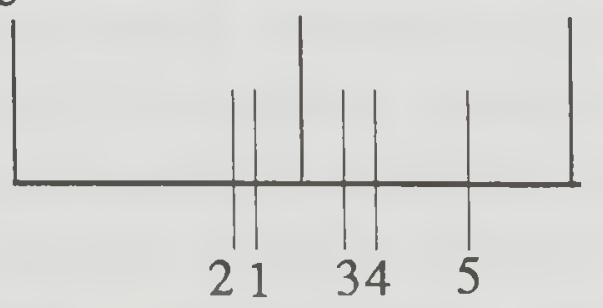

Abortion

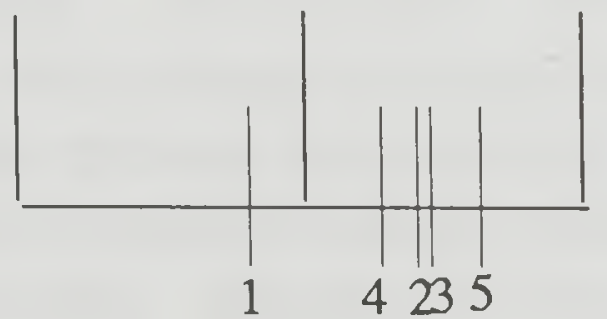

Women's Rights

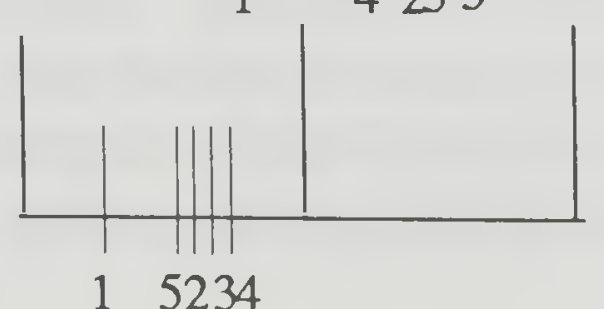

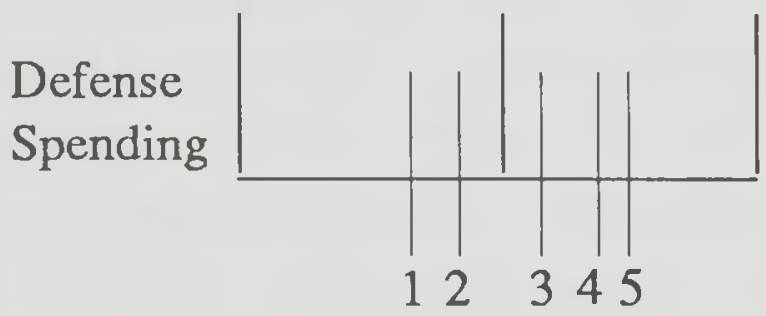
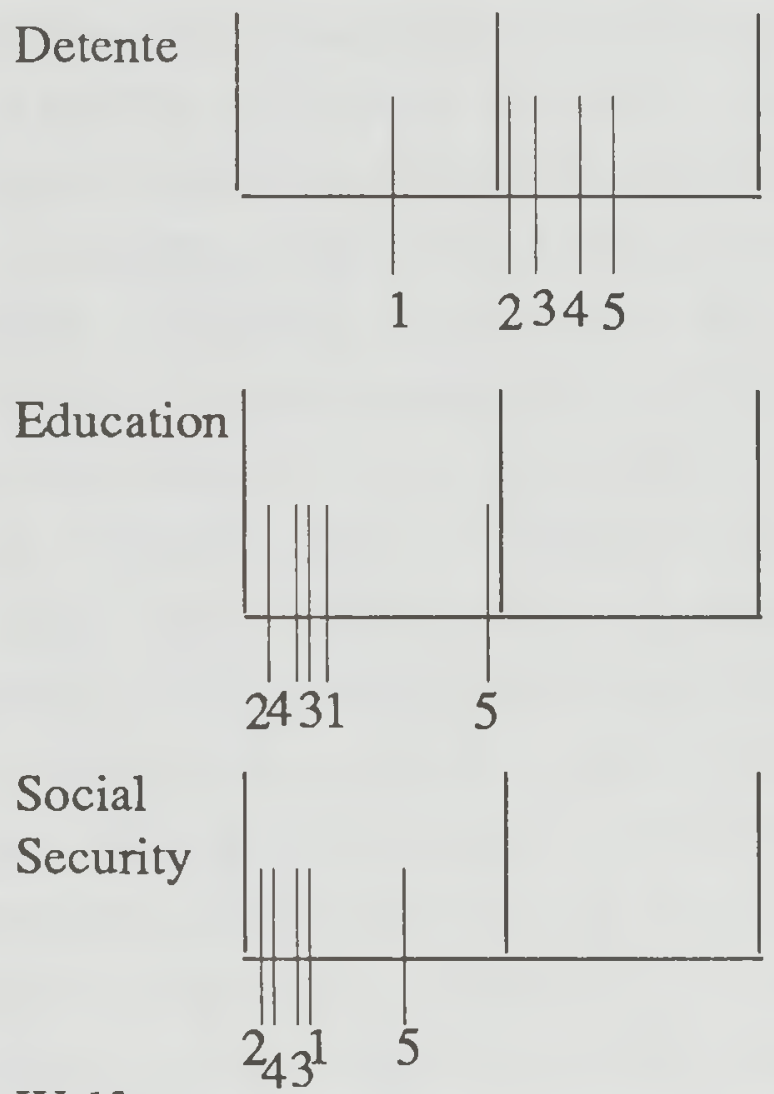

Welfare
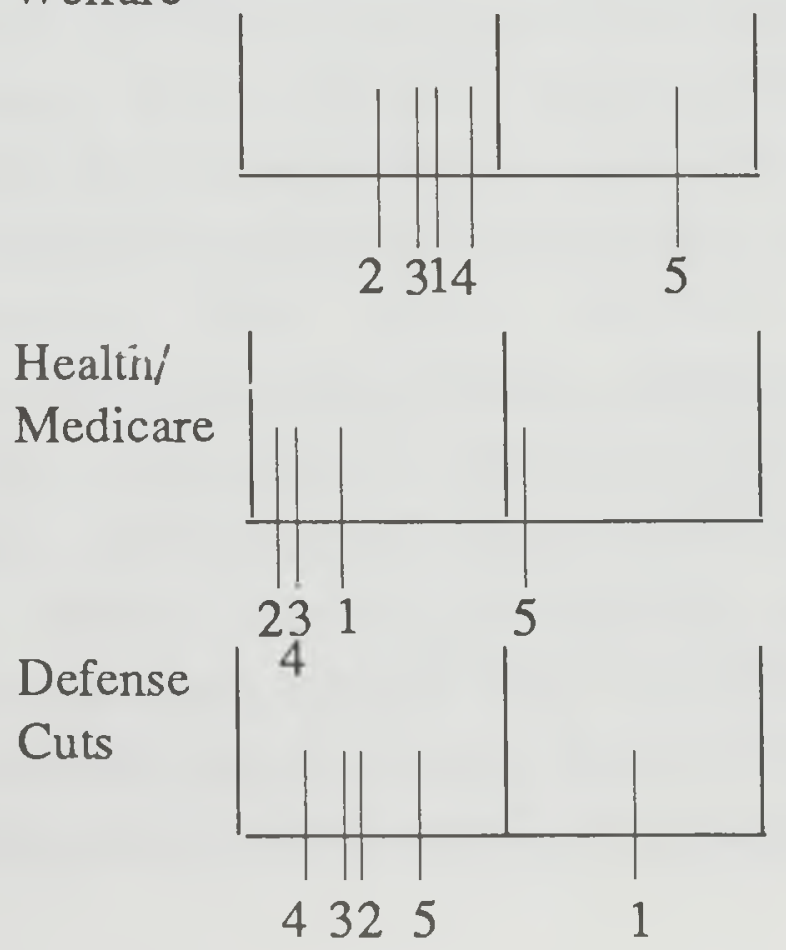
competitive two-party politics (Bass and Devries, 1976; Beck and Lopatto, 1982; Lamis, 1984), while others point to continued Democratic Party dominance at the state level raising the specter of dual partisan identification in the South (Hadley), 1985).

In the next section our analysis turns to a series of explicit domestic and foreign issues of public policy. For example, on the question of governmental services, i.e., reducing versus maintaining, southern party elites and mass voters continue to manifest a high degree of divergence in policy views. Southern Democratic leaders and followers are located on the left side of the political spectrum and are committed to a continuation of governmental services and federal spending. On the other hand, the first Reagan Administration's erfforts to curtail governmental services seems to have played well among southem Republican leaders and, to a lesser extent, followers. Southern Independents maintain a centrist posture on this issue with $68 \%$ registering a moderate response and the remaining $32 \%$ splitting evenly between the liberal and conservative positions.

On our second domestic policy question, respondents were asked whether "the government in Washington should see to it that every person has a job and a good standard of living." The conservative reaction of the southern GOP leaders is plainly demonstrated in Table 2 and Figure 2. No other issue, save that of welfare, elicits a stronger conservative response (77\%) from the upper echelons of the southem Republican Party. Surprisingly, the liberal end of the political spectrum is anchored by the southern Democratic rank-and-file where $37 \%$ of the respondents approve of federal intervention in this policy area. Moreover, southern Democratic indentifiers are significantly more liberal than the Democratic elites. Even Independents displayed larger liberal responses (28\%) than the southern Democratic leadership (20\%) who basically took a moderate position (62\%) on this issue. Republican identifiers tended to be skeptical of this policy as conservative reactions outnumbered liberal ones by a 2 to 1 margin.

Another issue with economic implications, national health insurance, clearly illustrates the odd-man out position of the southem GOP leadership and the level of homogeneity among southern voters and Democratic Party leaders. While southern Democratic elites and the confederate mass public gravitate toward middle-of-the-road positions, GOP leaders assume a much greater conservative stance. As depicted in Figure 2 and documented in Table 2, all groups except the Republican Party leaders are evenly divided on this policy issue with no 
response category greater than 59\%. On the other hand, southern Republican leaders are resolute in their dislike of a national health insurance program as measured by their conservative or anti-NHI (67\%) and liberal or pro-NHI (4\%) replies.

We can conclude then strong-to-moderate support for our hypotheses on this topic. As noted in Table 3, the policy stands of the southern Democratic Party leader are very much in step with those of the mass public, nor is there any major difference of opinion within the southern electorate itself. Only the responses of the GOP elites deviated significantly from our expectations.

Our next question was directed at the controversial issue of government's obligation to assist minorities. That is, the respondents were asked whether "the government in Washington should make every possible effort to improve the social and economic position of blacks and other minority groups, even if it means giving them preferential treatment." Despite four years of the Reagan Administration's somewhat successful efforts to reduce the scope and impact of affirmative action, liberal responses (pro-affirmative action) among all southern groups were relatively small. Not surprisingly, southern Democratic rank-andfile members, political base of the southern black voting population, were the most liberal group on this topic (28\%) edging out their party elders $(22 \%) .^{7}$ Southern GOP elites were least receptive towards the concept of affirmative action (49\% against), while party followers and Independents fell on the moderate-to-slightly conservative end of the political spectrum. The fact that southern Independents and GOP identifiers have not been swayed to either party's position underscores the importance of the white vote on this issue. Moreover, the differences of opinion between the Democratic identifiers, on the one hand, and the remaining mass voters of the South, on the other, suggest a certain amount of racial polarization on this issue. The issue of race itself is thought to explain much of Reagan's popularity among white southerners (Moyers, 1984), but others dismiss this argument as too simplistic (Stanley, 1986).

The conservative impact of religious fundamentalism is clearly documented on our next two issues - that of abortion and womens' rights. ${ }^{8}$ Beginning with abortion, southern voters are strongly united in their stand against this practice. Over $50 \%$ of southern Democrats, Republicans, and Independents oppose abortion under any circumstances. Republican elites are even more conservative than the public at large, with $66 \%$ opposing abortion under any circumstances and only 
$17 \%$ viewing abortion solely as a woman's choice. In contrast, southem Democratic elites deviate significantly from both the Republican leadership and the mass electorate with nearly half of the respondents favoring the liberal stance, i.e., the woman's choice position.

On the gender-related issue of whether women should be granted complete equality with men or adhere to their more traditional roles, some of the most unusual findings of this study are brought to light. First, as shown in Table 3, there is very little separating the conservative issue stands of the southern GOP elites, Independents, and Democratic and Republican rank-and-file,-conservative in that less than $50 \%$ of these respondents favored complete equality for women. Second, the strong liberal position of the southern Democratic elites, $70 \%$ proequality, served to effectively isolate them from all other groups on this issue. Third, on the basis of mean scores and conservative responses, GOP leaders were slightly more liberal on women's rights than the southern electorate. Undoubtedly, the atypical positioning of the southern GOP elites reflects the increasing significance of "gender-gap" politics in today's electoral campaigns (Goertzel, 1983; Mansbridge, 1985; Norris, 1985). Consequently, it is the Democractic elites that sharply diverge from prevailing southern opinion on this crucial issue.

In the next series of questions our analysis moves from domestic to foreign policy. The first question posed the dilemma of whether to increase, decrease, or maintain current levels of defense spending. As noted in Table 2 and graphically reaffirmed in Figure 2, southern Democrats and Republicans are arrayed along the political continuum from left to right. Support for current levels of defense spending was quite high among all groups, ranging from 59\% (Democratic identifiers and Independents) to $72 \%$ (GOP elites). Even $70 \%$ of southem Democratic leaders approved of 1984 defense spending levels, despite an unprecedented peace-time military build-up by the Reagan Administration. In a region steeped in military tradition these findings are not totally unexpected.

Unlike previous studies, however, GOP elites no longer closely mirror the responses of the mass public (Jackson et al., 1982). By 1984 only the southern GOP followers were closely aligned with the views of the Republican leadership. Democratic followers were located closer to their party leaders with southern Independents situated between the two extremes. Furthermore, the regional level of support for further increases in defense spending was rather low as measured by the conservative responses. This finding is somewhat prophetic in light of the second Reagan Administration's struggles to boost military 
expenditures.

On the issue of detente or "getting along with the Russians", the odd-man out status of the southern Democratic elites is unequivocally confirmed. The spatial distribution of mean values for this issue, displayed in Figure 2, distinctly depict a regional party leadership (the Democrats) out of step with the electorate. Whereas southern mass voters are wary of relations with the Soviet Union, the southern Democratic leadership clearly embraces it (45\% pro-detente and only $8 \%$ opposed to this policy). Southern Republican elites diverge sharply from their Democratic counterparts with only $19 \%$ favoring detente. In short, the views of the southern electorate are more closely reflected by the views of the Republic Party elites than those of the Democratic Party leaders on this particular issue.

The final series of questions ask whether certain programs should be cut in order to help balance the federal budget. From the results obtained it is evident that party elite cleavages are once again well defined. While southern GOP leaders singled out welfare (89\%), health/medicare $(51 \%)$, and education (49\%) as places to cute the budget, southern Democratic elites focused solely on defense $(77 \%)$. Social Security was the program least likely to be slated for any potential cuts, although $30 \%$ of the southern GOP elites did so identify it. On the other hand, welfare was the program of choice to cut among all groups except the Democratic elites.

Among southern mass voters there was a high level of homogeneity in their responses irrespective of program. Party rank-andfile and Independents were uniformly opposed to spending cuts in any program with the possible exception of welfare. (Approximately $40 \%$ of southern Independents and GOP identifiers advocated cuts in this area. (Only $28 \%$ of Democratic identifiers did so).

The relative positioning of the sourthern masses along the political continuum was also noteworthy in that they were consistently more liberal (anti-cuts) than either party elite groups regardless of program. It was also clear that aside from defense, the policy stands of the southern GOP elites diverged significantly from this same bloc of southern voters. Conversely, as noted in Table 3, the views of southern Democratic leaders and the mass public generally deviated very little from one another. Apparently, as one moves from economic (e.g., government services, job guarantees, NHI, and spending cuts) to social (e.g., Affirmative action, abortion, and women's rights) to military (e.g., defense and detente) issues, the gap between southern GOP elites and the 
southern masses narrows. On the other hand, the issue stands of the southern Democratic Party elites vis-a-vis the mass public tend to get further out of step while progressing along this same economic-socialmilitary continuum.

\section{Conclusion}

The unique and distinctive traits of the southern culture had suggested a level of political homogeneity undetected in previous nationwide political elite-mass voter studies. The results of this analysis provide only mixed support for this assessment, while furnishing some interesting similarities and contrasts to earlier elite-mass studies. Contrary to expectations, differences among southern Democratic and Republican Parties are real and palpable. Irrespective of issue/index the southern Democratic leaders are significantly more liberal/moderate than the conservative GOP elites. In purely spatial terms, the absolute division is not exceedingly large, but the fact that party elite cleavage is far more pronounced than that demonstrated by the more homogeneous southern electorate means that real, contextually relevant alternatives do exist for the southern masses.

Support for our elite-mass hypothesis was inconsistent as patterns of opinion distribution across the five groups fluctuated considerably from one issue to the next. Most notable was the position of the southern Democratic identifiers. On the seven of the thirteen issues surveyed, the Democratic rank-and-file were the most liberal group of respondents. In fact, on the issues of government job guarantees, welfare and health/ medicare cuts, southern Democratic identifiers were significantly more liberal than the Democratic leadership. Undoubtedly the sizable shift in white support from the Democratic Party to an Independent status, and more importantly since 1980, the Republican Party, helps account for this unusual finding (Stanley, 1988). Specifically, the southern Democratic Party base, by shedding its more conservative white elements and simultaneously attracting the more liberal black vote, has emerged in the 1980 s as fairly liberal body albeit fewer in numbers. If this process continues and the gap between Democratic identifiers and elites widens it could prove troublesome for the southern, and perhaps national, Democratic Party. The southem leadership would be faced with the dilemma of further liberalizing their issue positions at the risk of alienating additional partisan followers and recently converted Independents and Republican identifiers or moder- 
ating their stands and risk losing the liberal white and black vote. ${ }^{9}$

Despite this potential Catch-22 facing the Democratic Party, southern GOP victory is far from assured as witnessed by their extreme conservative stands vis-a-via GOP identifiers and Independents on a number of issues. Moreover, the rise in southern GOP identifiers and Independents has not proved all that helpful to candidates below the presidential and gubernatorial levels. State houses and elected executive branch officials are still heavily dominated by the Democrats. Yet, if the Republican leadership were to follow a Downsian strategy and shift closer to the moderate middle, the balance of power in the Deep South could conceivably tilt in their favor or at least mark the rise of a truly competitive two-party system. Ironically, the South's version of twoparty politics may someday hinge on a system dominated by a white Republican Party over a black Democratic one.

\section{Notes}

${ }^{1}$ Less comprehensive studies, i.e., state or county level of analysis or oneparty oriented, that support these nationwide elite mass findings include: Constantini (1963); Eldersveld (1964); Sullivan, Pressman, Page, and Lyons (1974); Commission on Presidential Nominations and Party Structure (1983); Stone and Abramovitz (1983); Hutter and Schier (1984); Browning and Shaffer (1987).

${ }^{2}$ The South to which we refer is the old Confederate South, i.e., Alabama, Arkansas, Florida, Georgia, Louisiana, Mississippi, North Carolina, South Carolina, Tennessee, Texas, and Virginia.

${ }^{3}$ Despite the wide use of region in scholarly efforts, the task of defining this concept has been elusive (Isard and Reiner, 1968; Sharkansky, 1970; Markusen, 1987). For the purposes of this paper, we will define region in the following manner:

A region is an historically evolved, contiguous territorial society that possesses a physical environment, a socio-economic, political, and cultural milieu, and a spatial structure distinct from other regions and from other major territorial units, city or nation (Markusen, 1987, 16-17).

(For a good discussion on the alternative approaches to the study of regions and regionalism, see Markusen, 1987, 249-266).

${ }^{4}$ Studies dealing with the South as a separate political system are far too numerous to list here. An excellent bibliography of them is provided in The Changing Politics of the South, ed. William C. Harvard (Baton Rouge: Louisiana State Press, 1972), pp. 736-738.

${ }^{5}$ See John S. Jackson (1985).

6 A comparison of the known characteristics of the universe and the characteristics of the sample revealed no recognizable biases in the sample (Jackson, 1985). 


\section{Policy Preferences of Party Leaders and the Public}

${ }^{7}$ The Democratic Party in the South includes a substantial and growing number of black voters. Measurement and analysis of this phenomenon, with regard to southem politics, is beyond the scope of this article and will be addressed in a later study.

${ }^{8}$ Compared with states outside the Confederate South, collective southern liberal responses were ten percentage points less than those of their nonsouthern counterparts for both abortion and women's rights. Mean scores for southern responses on these two issues were also significantly more conservative than the nonsouthern responses $(\mathrm{t}$-test, $<.05)$.

${ }^{9}$ Recent developments suggest that national party strategists are already attempting to diffuse this situation by appealing to both conservative white southerners (e.g., Texan Lloyd Bentsen as the 1988 Democratic nominee for vice-president) and liberal black voters (e.g., formal acceptance of Jesse Jackson as a major player in the Democratic Party). This bold, but risky, strategy reflects the major importance of this region in national politics.

\section{References}

Bartley, N.V. (1969). The Rise of the Massive Resistance. Baton Rouge: Louisiana State Univ. Press.

Bartley, N.V., \& Graham, H.D. (1975). Southern Politics and the Second Reconstruction. Baltimore: John Hopkins University Press.

Bass, J., \& Devries, W. (1976). The Transformation of Southern Politics. New York: Basic Books.

Beck, P.A. \& Lopatto, P. (1982). "The End of Southern Distinctiveness." In Laurence Moreland, Tod Baker and Robert Steed, eds., Contemporary Southern Political Attitudes and Behavior (160-182). New York: Praeger.

Black, E., \& Black, M. (1982). "'Successful Durable Democratic Factions in Southern Politics." In Laurence Moreland, Tod Baker and Robert Steed, eds., Contemporary Southern Political Attitudes and Behavior (99-120). New York: Praeger.

Browning, R.X., \& Shaffer, W.R. (1987). “Leaders and Followers in A Strong Party State." American Politics Quarterly, 15: 87-106.

Burnham, W.D. (1976). "The Onward March of Party Decomposition." In Richard Niemi and Herbert Weisberg, eds., Controversies in American Voting (422432). San Francisco: W.H. Freeman and Company.

Champion, D.J. (1981). Basic Statistics for Social Research. (2nd ed.). New York: Macmillian.

Commission on Presidential Nominations and Party Structure (1978) "Openness, Participation and Party Building: Reforms for a Stronger Democratic Party." Washington, DC: Democratic National Committee.

Constantini, E. (1963). "Intraparty Attitude Conflict: Democratic Party Leadership in California." Western Political Quarterly, 16: 956-972.

Crotty, W. (1984). American Parties in Decline. (2nd ed.) Boston: Little, Brown and Company.

Elazar, D.A. (1984). American Federalism. 3rd ed.). New York: Harper \& Row.

Eldersveld, S.J. (1964). Political Parties: A Behavioral Analysis. Chicago: Rand 
McNally.

Eldersveld, S.J. (1982). Political Parties in American Society. New York: Basic Books.

Everson, D.H. (1980). American Political Parties. New York: New Viewpoints Press.

Goertzel, T.G. (1983). “The Gender Gap: Sex, Family Income and Political Opinions in the Early 1980's." Journal of Political and Military Sociology, (Fall): 209-222.

Hadley, C.D. (1985). "Dual Partisan Identification in the South." Journal of Politics, 47: 254-268.

Havard, W.C. (1986). "Southern Politics: A Prelude to Presidential Politics in 1984." In Robert Steed, Laurence Moreland and Todd Baker, eds., The 1984 Presidential Election in the South (3-17). New York: Praeger.

Hill, C.E. (1977). "Anthropological Studies in the American South: Review and Directions." Current Anthropology, 18: 309-314.

Hitlin, R.A., \& Jackson, J.S. (1979). "Change and Reform in the Democratic Party." Polity, II: 617-633.

Hutter, J.L., \& Schier, S.E. (1984). “Representativeness: From Caucus to Convention in Iowa." American Politics Quarterly, 12: 431-448.

Isard, W., \& Reiner, T.A. (1968). "Regional Science." International Encyclopedia of the Social Sciences, 13: 382-390.

Jackson, J.S. (1985). “Political Party Leaders and the Mass Public: 1980-1984." Paper delivered at the Annual Meeting of the Midwest Political Science Association, Chicago, Illinois, April 19.

Jackson, J.S., Brown, B.L., \& Bositis, D. (1982). “Herbert McClosky and Friends Revisited." American Politics Quarterly, 10: 158-180.

Key, v.O., Jr. (1949). Southern Politics. New York: Knopf.

Kirkpatrick, J. (1976). The New Presidential Elite. New York: Russell Sage Foundation.

Kirkpatrick, J. (1978). Dismantling the Parties. Washington, D.C.: American Enterprise Institute for Public Policy Research.

Konda, T.M., \& Sigelman, L. (1987). "Public Evaluations of the American Parties, 1952-1984." Journal of Politics, 49: 814-829.

Ladd, E.C., Jr. (1982). Where Have All the Voters Gone? (2nd ed.). New York: W.W. Norton.

Lamis, A.P. (1984). The Two-Party South. New York: Oxford University Press. Leiserson, A. (1958). Parties and Politics. New York: Knopf.

Mansbridge, J.J. (1985). "Myth and Reality: The ERA and the Gender Gap in the 1980 Election." Public Opinion Quarterly, 49: 164-178.

Markusen, A. (1987). Regions: The Economics and Politics of Territory. Totowa: Rowman \& Littlefield.

McClosky, H., Hoffman, P.J., \& O'Hara, R. (1960). "Issue Conflict and Consensus Among Party Leaders and Followers." American Political Science Review, 54: 406-429.

Miller, A.H., \& Wattenber, M.P. (1983). “Measuring Party Identification: Independent or No Partisan Preference?' American Journal of Political Science, 27: 106-121. 
Montjoy, R.S., Shaffer, W.R., \& Weber, R.E. (1980). “Policy Preferences of Party Elites and Masses: Conflict or consensus?" American Politics Quarterly. 8: 319-344.

Moyers, B. (1984). CBS Election Night Coverage, November 6.

Norris, P. (1985). "The Gender Gap in Britain and America." Parliamentary Affairs, 38: 192-201.

Ranney, A. (1962). The Doctrine of Responsible Party Government. Urbana: University of Illinois Press.

Reed, J.S. (1982). One South: An Ethnic Approach to Regional Culture. Baton Rouge: Louisiana State Univ. Press.

Sabato, L.J. (1988). The Party's Just Begun. Glenview, Illinois: Scott, Foreman and Company.

Sharkansky, I. (1970). Regionalism in American Politics. New York: Bobbs - Merrill. Sorauf, F.J. (1984). Party Politics in America. (5th ed.) Boston: Little, Brown and Company.

Sorauf, F.J., \& Beck, A.P. (1988). Party Politics in America. (6th ed.). Glenview, Illinois: Scott, Foresman and Company.

Stanley, H.W. (1986). "The 1984 Presidential Election in the South: Race and Realignment." In Robert Steed, Lawrence Moreland and Tod Baker, eds., The 1984 Presidential Election in the South (303-335). New York: Praeger.

Stanley, H.W. (1988). "Southern Partisan Changes: Dealignment, Realignment or Both?"' Journal of Politics, 50: 65-68.

Stone, W.J., \& Abramowitz, A.I. (1983). “Winning May Not Be Everything, But It's More Than We Thought: Presidential party activists in 1980." American Political Science Review, 77: 945-956.

Sullivan, D.G., Pressman, J.L., Page, B.I., \& Lyons, J.J. (1974). The Politics of Representation. New York: St. Martin's Press.

Whistler, D.E., \& Ellickson, M.E. (1988). “Measuring Influence in a Southern State Legislature." Paper delivered at the Annual Meeting of Westem Social Science Association, Denver, Colorado, April 28. 